\title{
QUALITATIVE AND QUANTITATIVE DISTINCTIONS BETWEEN LEXICAL ACCENTS OF STANDARD SERBIAN IN THE SPEECH OF NOVI SAD (MINIMAL PAIR CORPUS)*
}

The paper reports the results of the study of qualitative and quantitative distinctions between lexical accents in Standard Serbian. The study is based on the analysis of the largest corpus of minimal pairs investigated so far, produced by 14 speakers from Novi Sad. The paper gives the description of the realizations of accents, as well as the statistical analysis of the acoustic measurements conducted. The qualitative distinctions are most reliably marked by F0 range between the ending of the stressed vowel and the onset of the next one, which is realized as a downward shift in falling accents, and as an upward shift in rising accents. The other parameters observed, concerning the tonal and intensity relations between the stressed and the following vowel, can be viewed as subsidiary phenomena of the accent quality. The quantity distinctions between short and long falling and rising accents are based on the durational differences of the stressed vowels, and partly on the relationship between the duration of the stressed and the following vowel.

Key words: lexical accent, quality, quantity, fundamental frequency, duration.

У раду су представљени резултати истраживања квалитетских и квантитетских дистинкција између акцената стандардног српског језика. На основу анализе досад највећег корпуса минималних парова, који је реализовало 14 говорника новосадског порекла, описане су реализације акцената, а резултати акустичких мерења подвргнути су статистичкој анализи. Квалитетске дистинкције најверније одражава распон f0 између краја наглашеног и почетка наредног вокала, који је код силазних акцената силазан, а код узлазних - узлазан. Остали посматрани параметри тонског и интензитетског односа између наглашеног и наредног вокала могу бити пратилачки феномен акценатског квалитета. Квантитетске дистинкције између силазних, као и између узлазних акцената, почивају на разликама у трајању наглашених вокала, а делом и на разликама у односу трајања наглашеног и наредног вокала.

Кључне речи: акценат, квалитет, квантитет, фреквенција основног тона, трајање.

1. Introduction. Contemporary phonological description of lexical (word) accent in Standard Serbian should be based on the present-day, elaborate descriptions of its phonetic realizations in different Štokavian spoken dialects (those with six prosodemes, but also in those with a lesser number of prosodemes), as well as on detailed studies of word stress perception. Phonetic studies into word accent, conducted by researchers whose native language is Serbian ${ }^{1}$, are abundant in the literature: starting from the ground-breaking study by Pavle Ivić and Ilse Lehiste

* The study was financed by the Ministry of Education, Science and Technological Development of the Republic of Serbia under the Research grants III 47040, TR32035 and OI178002.

${ }^{1}$ In the papers of some researchers the drawbacks were in the selection of corpora and the interpretation of data, caused by the fact that the authors themselves were not native speakers of Serbian (Ивић - Лехисте 1996: 165-169; SRedojević 2017c: 202-204). 
(Ивић - Лехисте 2002) ${ }^{2}$, through the studies conducted by Jelica Jokanović-Mihajlov (ЈокАновић-МихАллов 1983; 2007), several PhD dissertations written in the past ten years (СРЕДОлЕВИЋ 2011; БАТАС 2016; ЛончАР РАИЧЕВИЋ 2016б) and a number of studies looking into the phonetic characteristics of accents in different Štokavian dialects (Средолевић 2009a; SRedojević - Subotić 2011; Средолевић - Суботић 2011; Средолевић - СПасић 2016; Sredojević 2015; 2016a; 2016b; 2017a; 2017b; 2017c; 2020; Лончар РАичевић 2016a; Лончар РАичевић - СудиМАЦ 2017; 2018).

Although the corpus of research studies is considerable, unfortunately, it may not be reliable for the contemporary phonological description of accents in Serbian for several reasons. Firstly, the corpus is not fully representative of the contemporary language. Due to the wars, the consequent economic crises and migrations over the past three decades in the region, the dialectal structure of population has changed considerably. In addition, the same period has been marked by a general deterioration of general linguistic and verbal culture (at schools and electronic media, especially television), so that the realization of accents in the spoken language of educated people in cultural and economic centers has also changed and is therefore highly unlikely to be comparable to Ivić and Lehiste's findings from 60 years ago.

Secondly, the corpus investigated thus far is not diverse enough. In other words, in the bulk of research studies reported so far, the typical realizations of some wellknown and widely recognizable dialects, such as those of Sremska Mitrovica, Sabac, Valjevo, Kikinda or Subotica, as well as those of towns in Serbia outside the territory of Neo Stokavian dialects or Serbian dialects in the neighboring countries, have not been studied at all.

Thirdly, the results of the studies are widely variable. This is due to the methodological differences between these studies, such as the procedures, the amount and content of spoken materials analyzed, as well as the interpretation of the results, which makes it rather difficult to compare the results. As a result, it is not easy to come up with a reliable description of accents in Serbian, and concerning the existing ones, there is no clear consensus on them among researchers.

This inconsistency among the authors is the most conspicuous in different phonological interpretations of Neo Stokavian accents ${ }^{3}$, where some authors define rising accents as those containing a high tone in the following mora, divided by syllabic boundaries, wherefore they regard them as disyllabic (Ivić, ${ }^{4}$ Inkelas and Zec, ${ }^{5}$

\footnotetext{
${ }^{2}$ The results of the research were published in Serbian and foreign scientific journals from 1963 to 1984, and the integral version was published in Ивић - Лехисте 2002.

${ }^{3}$ This term is used since the prosodic norms of the preset-day standard Serbian and Croatian are based on the Neo Štokavian system, containing six prosodemes (four stressed and two unstressed). The researchers we refer to in the paper described this system, although many of them for hystoric or sociolinguistic reasons called the language Serbo-Croatian (Ivić and Lehiste (2002), Sharon Inkelas and Draga Zec (InKelas - Zec 1998), Svetlana Gođevac (Godjevac 2000; 2005)), Croatian (JelaskA 2004; Pletikos 2008) or Serbian (SRedojević 2017).

${ }^{4}$ The relevant parameters are quantity and stress placement. Accent can be placed at syllabic boundary at the syllable onset, and realized as higher pitch in the following morae. Falling accents are monosyllabic, while rising accents are dysyllabic. (Ивић 1998: 480-481).

${ }^{5}$ Phonologically relevant features are the tone and stress, which is phonetically manifested as longer duration. Tones are assigned to morae, and not to syllables. Accents consist of high and low
} 
Pletikos ${ }^{6},{ }^{7}$ while others believe that rising accents are realized as the sequence of a low tone in the stressed and a high tone in the following syllable (Godjevac, ${ }^{8}$ Jelaska, ${ }^{9}$ Sredojevicí ${ }^{10}$ ). Our motivation to undertake this research was to come up with reliable data that may be used as the basis for a contemporary description of accents in Standard Serbian. In order to establish the fundamental distinctions between the qualitative and quantitative characteristics of different accents, we analyzed and described the largest corpus of minimal pairs so far, and conducted a thorough statistical analysis of the acoustic measurements in order to establish precise differences between them. The corpus comprises materials read by educated speakers from Novi Sad, the second largest city in the Republic of Serbia ${ }^{11}$. Once similar studies are conducted among other representative areas of the Serbian language community, and once they are complemented by thorough research into the perception of contemporary accents, it will be possible to come up with a reliable and contemporary phonological description of word accent in the Serbian language.

The results of the research are to be presented in the following way. Following the Introduction, we proceed by the overview of the results of previous research, which we shall subsequently compare to our results. The third chapter deals with the research methodology applied, presenting the participants, corpus and description of the acoustic variables analyzed. It is followed by the results obtained in this research and comparison with those of previous researchers. In the final chapter we sum up the main conclusions we have reached.

tones, and the information on stress is predictable from the information on tone. Falling accents reside within a single syllable, while rising accents "stretch" over two syllables, the first of which is perceived as stressed. (INKELAS - ZEC 1988: 228).

${ }^{6}$ The author finds that the "initial pitch level of the poststressed syllable in relation to the total pitch level of the stressed syllable the most relevant feature for distinguishing between falling and rising accents" (PLETIKOS 2008: 215). Long rising accent is essentially the sequence of high tonal levels extending over the whole stressed syllable, encompassing the following syllable, while short rising accent is a sequence of two high tonal levels.

${ }^{7}$ This statement was made for the first time in 1876, based on auditory analysis by the Slavist of Estonian origin, Leonhard Masing (MASING 1876).

${ }^{8}$ Accent is a sequence of two tones grouped around the stressed syllable. Two falling accents are achieved as falling melody, composed of a high tone and a low tone following it, the high one being tied to the unit which carries the tone and the stressed syllable. The two rising accents achieve rising melody, and they are represented by the sequence of a low tone in the stressed unit, and a high tone following it (GODJEVAC 2005: 148-149).

${ }^{9}$ Phonologically relevant are stress, length and tone. The carrier of stress is a syllable, and the carrier of tone is a mora (JELASKA 2004: 210-211). Merged falling tones are a sequence of a high tone in the stressed syllable (stress can only be assigned to the first mora if the syllable is long) and a low tone (two components of prominence, stress and high tone, are merged in the same syllable). Words with merged rising tone have two prominent features divided in two subsequent syllables, stress being on the first, high tone on the second.

${ }^{10}$ Syllable is the carrier of stress, marked by relatively longer duration of its vocalic nucleus. Falling tones are achieved as a sequence of high and low tone, and rising ones as a sequence of low and high tone. Tones are related to morae, they are divided by syllabic boundaries, and the first of the two tones belongs to the stressed syllable (SREDOJević 2017: 223).

${ }^{11}$ Novi Sad is the capital of the Autonomous Province of Vojvodina and the second largest city in the Republic of Serbia. It is located at $45^{\circ}$ to $46^{\circ}$ north latitude and $19^{\circ}$ to $20^{\circ}$ east longitude. According to the census from 2011, Novi Sad had 341625 inhabitants, 307760 of whom inhabit the inner city area (ЛАКчевић и др. 2014: 23). The city of Novi Sad has $20.16 \%$ university educated inhabitants, $23.26 \%$ of whom are in the inner city (ЛАКчевић и др. 2013: 46-47). 


\section{Previous Research}

2.1. Pavle Ivić and Ilse Lehiste investigated the realization and perception of accents in Serbo-Croatian for over twenty years, as well as sentence intonation and its impact on the realization of lexical accent. For the length of their research, the scope of the phenomena the authors strived to describe, the size of corpora investigated and the number of associates engaged, Ivić and Lehiste's studies were the most thorough investigation into the prosodic characteristics of word and sentence prosody in Serbo-Croatian. The bulk of the spoken materials analyzed was recorded by Ivić himself, who was born in Vojvodina and spent most of his life in that region prior to the research. Additional and lesser amount of the corpus was produced by 12 additional subjects, mainly radio news readers, most of whom were also of Vojvodina origin (Ивић - ЛЕхисте 2002: 11, 83-84). ${ }^{12}$

2.1.1. In Ivić's examples of words with long falling accents in the medial sentence position, ${ }^{13}$ stressed vowel has a falling or rising-falling tonal slope (with the tone peak around the first quarter of the duration of vowel), and is followed by a vowel with a lower tonal peak and a falling tonal slope. In the group of the 12 additional subjects, one subject mainly exhibited rising tone on the stressed vowel, one female subject had mildly falling movement and the others had markedly falling tonal slopes, with the peak close to the onset of the vowel in most subjects' production (Ивић - Лехисте 2002: 109-113). ${ }^{14}$ In Ivić's pronunciation of words with long rising accents, the stressed vowel has a rising tendency (with the tonal peak towards the vowel ending), and it is followed by a vowel that may have a somewhat higher tonal peak. The following vowel generally has a falling tendency (Ивић - Лехисте 2002: 32-33, 38-39). Although the authors find that the tonal movement found in Ivićs production is present among the additional 12 subjects, a more detailed analysis of their examples reveals that their realizations are highly variable (Ивић - Лехисте 2002: 89). Two of the subjects had a falling slope in the stressed vowel, six had a mildly rising slope, and only four pronounced it as markedly rising. The relation between the peak of the stressed and the following vowel in nine speakers' pronunciation is realized as an upward shift (Ивић - ЛЕХисте 2002: 110-112).

Ivić's production of short falling accents is mainly characterized by a falling tonal slope on the stressed vowel (with the peak around the mid portion of the vowel), falling slope on the following vowel and a downward shift between the two vowels. On the other hand, some of the short falling accents produced by the

${ }^{12}$ In the studies by Ivić and Lehiste the data on F0 obtained from materials read by Ivić are represented as mean values, while the values of F0 obrained from the twelve additional subjects are divided into three groups according to the pitch of their voice, and the data of each of the groups is represented in mean values. The authors did not test the statistical significance of differences in the parameters observed for falling and rising, short or long accents, and the conclusions were reached based on the analysis of all words and not only minimal pairs.

${ }^{13}$ In this paper we shall refer only to those Ivić and Lehiste's data related to the medial position in declarative sentences, since this position is equivalent to that used in our examples from the corpus of minimal pairs.

${ }^{14}$ Yet, upon a closer inspection of the tables in the Appendix, one can notice that in words with long falling accents seven speakers had higher pitch at the onset of the unstressed vowel than at the ending of the stressed vowel (Ивић - Лехисте 2002: 90-104). 
additional subjects are realized with a rising tonal slope, while the other features are the same as those described in Ivić's pronunciation (Ивић - Лехисте 2002: $18-21,90-104)$. The author's short rising accents are mainly realized with a rising tonal slope on the stressed vowel, a falling slope on the subsequent vowel and an upward tonal shift between the two. The realization of the same accent in the additional group differed in terms of the tonal movement on the stressed vowel. In this group, most words are characterized by a falling slope on the stressed vowel. Since $75 \%$ of words with short falling accents are characterized by the same tonal movement, the authors conclude that the tonal movement on short stressed vowels is phonologically irrelevant (Ивић - ЛЕхисте 2002: 25-29, 109-113).

With reference to the phonological implications of the phonetic description of accents, Ivić and Lehiste point out that the distinctive features of accents cannot be determined inside the stressed syllable. Yet, although the F0 shift within the short stressed vowels is redundant, that is not the case with long vowels, since words with a long falling accent do exhibit falling pitch tendency, while the stressed long rising accents exhibit mildly rising or level pitch. The authors conclude that the main qualitative distinction is achieved by "the relation between the stressed and the following syllable" (Ивит - Лехисте 2002: 153-156), ${ }^{15}$ and that the distinction among long accents is additionally achieved by the tonal movement inside the stressed vowel (Ивић - ЛЕхисте 1996: 58; 2002: 155).

2.1.2. As Ivić and Lehiste state, in the examples produced by Ivić, the intensity relations between the stressed and the following syllable tend to be descending with falling accents, while rising accents may be followed by ascending intensity values (Ивић - Лехисте 2002: 41-45). In the examples of words pronounced by the twelve subjects, the differences in the intensity of the stressed and the following vowel were related to the changes in F0 in some speakers' production, but in others' this relationship was not observed (Ивић - ЛЕхисте 2002: 115). The authors conclude that intensity is not a relevant parameter of quality distinctions (Ивић - ЛЕхисте 2002: 46).

2.1.3. Concerning quantitative distinctions, Ivić and Lehiste observe that in Ivićs production the ratio between the duration of vowels with long and short falling accents is somewhat over $3: 2$, while the same ratio with long and short rising accents is a little below $3: 2$ (Ивић - Лехисте 2002: 31,36). In the speech of the twelve subjects the authors find confirmation of the same relations as in Ivićs production, with the ratio of long to short vowels $1.6: 1$ (Ивић-ЛЕхисте 2002: 119).

2.2. In her research, Jelica Jokanović-Mihajlov investigated accent and intonation in the spoken language of radio and television news readers from Belgrade area and reported her results in her seminal study (2007). Her main corpus, represented by political news programs, recorded in the period from 1984 to 1985 , was analyzed in her $\mathrm{PhD}$ thesis, and was later complemented by news programs recorded in the periods 1994-1996 and 2004-2006. Among the results reported, we shall mainly look into those concerning speakers of Vojvodina origin, although

${ }^{15}$ It should be noted that the authors do not precisely state whether they refer to the tonal peaks or the relation between F0 of the stressed vowel ending and the onset of the following vowel. 
the comparison with our results is not always possible due to different research methodologies applied. This is due to the fact that Jokanović-Mihajlov provides the values of F0 or durational values (rarely both) only selectively for some examples, while the intensity values are not reported.

2.2.1. In the description of falling accents produced by speakers of Vojvodina origin, Jokanović-Mihajlov briefly states that their realization of accents is comparable to those of Belgrade origin - stressed vowels are mainly characterized by a level tone, while the next syllable has a lower pitch than the stressed syllable, which is a phonologically relevant feature of falling accents (Јокановић-Михаллов 2007: 70-91). In words with a short falling accent the speakers of Vojvodina origin tend to have a falling tone, continued on the following vowel, while the stressed vowel of the syllable with a short rising tone may have a rising tone, which continues onto the following vowel (Јокановић-Михаллов 2007: 94). The author concludes that in short accents the main realization is a level tone on the stressed vowel and the phonologically relevant pitch level of the subsequent syllable, which is higher in words with rising accents, and lower in those with falling accents (ЈокАновић-МиХАЈЛОВ 2007: 78).

2.2.2. In relation to intensity, the author briefly states that both falling and rising accents involve an even distribution between the stressed and the following vowel, or that the vowel following the stressed one may be more dominant in intensity (Јокановић-Михаллов 2007: 71-96).

2.3. The results of our study will also be compared to the results reached by Dejan Sredojević in his research into the phonetic characteristics of word accents of Standard Serbian in the period from 2007 to 2017, based on the corpus investigated for his doctoral dissertation and in his subsequent studies. In the study SREDOJEVIĆ 2015a, based on the corpus of sentences, the author analyses the realization of long accents by 8 speakers from Novi Sad, while in SrEDoJEvić 2016, the corpus involved longer read texts, and the focus of this research is the realization of short accents in six speakers from Srem, six from Bačka and six from Banat. In SREDOJEVIĆ $2017 \mathrm{c}$, the author reports the results of a most comprehensive research of accents in Standard Serbian. In this study, vowels of 4500 recorded words were manually segmented and a selection of acoustic variables were consistently analyzed. The materials were produced by 45 educated speakers of Novi Sad origin, aged 19 to 45 . The corpus included sentences, read texts and minimal pairs. The values measured were statistically analyzed in order to establish whether the parameters differed significantly among the groups of words analyzed - depending on the length, quantity or quality of the stressed vowel, the quantity and quality of the unstressed vowel or the position of the word in the intonation phrase.

2.3.1. Sredojević's findings related to long accents in the speech of Novi Sad indicate that words with an equal number of syllables exhibit statistically significant differences between the two accent types. The significant parameters are the range of F0 between the onset and ending of the stressed vowel, although both accent types most frequently involve a falling tonal slope on the stressed vowel. Long falling accents are characterized by a downward tonal shift between the stressed and the following vowel, while rising accents involve an upward shift. 
The differences in the parameter describing the range of F0 between the ending of the stressed and the onset of the following vowel are statistically significant, and so is the range between the tonal peaks of the two vowels (SREDOJEVIĆ 2015a: 339-341).

In the speech of Srem, Banat and Bačka, Sredojević finds that vowels with a short falling accent tend to have a rising tonal slope, while a falling tonal slope most frequently accompanies vowels with short rising accents. Yet, these tendencies are not consistently found in either one of the short accents, which leads to the conclusion that this cannot be relevant for establishing phonological distinctions of accent quality. On the other hand, short falling accent regularly entails a downwards shift between the stressed and the following vowel, while short rising accent involves an upward shift. The mean values of F0 range between the onset and ending of the stressed vowel, between the ending of the stressed and the onset of the following vowel and between the F0 peaks of the two are significantly different in words with short accents in all three speeches analyzed.

In SREDOJEVIĆ 2017c the author finds that minimal pairs of words with long accents are regularly characterized by a falling tonal slope on the stressed vowel. In both long accent types the F0 value in the initial portions of the vowel is higher than towards its ending, although the fall is more prominent in falling accents. In words with long falling accent, the stressed and the following vowel are divided by a downward tonal shift, while those with long rising accents are followed by an upward shift. The tonal peaks of the stressed and the following vowel are in the descending order in words with long falling accent, and in the ascending order in words with long rising accent.

The analysis of the minimal pair corpus with short accents reveals that the tonal slope on the stressed vowel is mainly falling in all the words with short rising accent analyzed, in trisyllabic words with short falling accent it is mainly rising, while in disyllabic words with falling accent both falling and rising slopes are found. In minimal pairs of words with short accents there is a descending tonal interval in words with falling accent, and an ascending one in rising accents. In terms of the mean values of F0 range from the onset to the ending of the stressed vowel, the range from the ending of the stressed and the onset of the following vowel and the F0 peaks of these consecutive vowels are all significantly different between the minimal pairs with long accents, as well as between the short ones (SREDOJEvić 2017c: 126-130).

In the medial intonation phrase position, the stressed vowels with falling accents may have a falling, rising or rising-falling tonal slope, while the subsequent unstressed vowels have a falling slope. The stressed vowel ending is followed by a descending tonal interval to the onset of the following vowel, and the tonal peaks of the stressed and unstressed vowels are in the same relation. The most prominent tonal peak is found in the stressed vowel. In contrast, the stressed vowels in words with rising accents are most frequently characterized by a descending tonal slope. The ending of the stressed vowel and the onset of the following vowel, as well as their respective peaks, are divided by an ascending tonal interval. The vowel following the stressed one may have a rising or a falling tonal slope, and its peak is, in most cases, the most prominent one in the word (SREDOJEVIĆ 2017c: 219-220).

Based on the analysis of the whole corpus in SREDOJEVIĆ 2017c, the author concludes that the tonal relation between the ending of the stressed vowel and the 
onset of the following one is the most consistent marker of accent quality. The distinctive feature of falling accents is a descending interval between the ending of the stressed and the onset of the following vowel, and it is found in all the words in all positions in all the corpora analyzed, while an ascending interval between the two vowels is the distinctive feature of rising accents, also found in all positions of words in the corpora. The values of F0 range between the ending of the stressed and the onset of the following vowel in words with equal numbers of syllables, equal quantity of the stressed vowel and the same position in the intonation phrase are significantly different in words with falling and rising accents in all the corpora analyzed (SREDOJEvić 2017c: 221-222). Sredojević states that the realizations of accent described by Masing and later reported in the studies by Ivić and Lehiste are typical of the Serbian language, and are still common in certain speeches of Neo Stokavian dialects, but the "phonological description of falling accents as monosyllabic and rising as disyllabic (implying a high tone on the subsequent morae separated by syllabic boundaries) - is not correct", and the author argues that the phonetic realizations which might support Ivić and Lehiste's claim are not common in all speeches of Neo Štokavian dialect territory (SREDOJEvić 2017c: 198).

2.3.2. Analyzing long accents in the speech of Novi Sad, Sredojević found that in words with long falling accent there is generally a downward shift in intensity between the stressed and the following vowel, while in long rising accents, intensity more frequently exhibits a rising trend, while the mean value of intensity difference is lower than $1 \mathrm{~dB}^{16}$. The mean intensity values of the two vowels are significantly different among disyllabic and trisyllabic words with long accents for both accent types (SREDOJEvić 2015a).

Sredojević's analysis of short accents in the production of speakers of Srem, Banat and Bačka origin reveals that words with short falling accent are characterized by a greater descending intensity relation between the stressed and the following vowel compared to words with short rising accents. The stressed vowel is always more dominant in terms of intensity in words with short falling accent, while the unstressed vowel is most frequently dominant in words with short rising accent, but in some of the examples, the differences in intensity of the two vowels (in both accent types) are below perception threshold (SREDOJEvić 2016: 287).

In SREDOJEVIĆ 2017c, the author analyses several different corpora, and the findings indicate that the intensity parameters (I1 - I2) are significantly different between words with falling and rising accent in sentences, minimal pairs and in read texts (SREDOJEVIĆ 2017c: 172-174). ${ }^{17}$ The relation between the intensity of the stressed and the following vowel is more commonly descending in words with falling than with rising accents, and it is also more marked in falling accents. Considering that ,there is no specific intensity relation between the stressed and the following vowel that would typically characterize solely falling or solely rising accents", the author concludes that intensity is only a subsidiary feature of accent (SRedojević 2017c: 223).

${ }^{16}$ Change of intensity of $1 \mathrm{~dB}$ is the lowest perceptible intensity change that we perceive as change in loudness (FLanagan 1957, quoted in Lehiste 1977: 116).

${ }^{17}$ Differences in intensity levels are not statistically significant in some groups of words with short accents: trisyllabic in the corpus of test-sentences and dysyllabic in the corpus of minimal pairs. 
2.3.3. In terms of duration, Sredojević finds that in the corpus of minimal pairs, the phonologically long vowels in syllables with falling accent is on average 1.5 times longer than the phonologically short vowels analyzed, while in words with rising accents, the long vowel is 1.34 longer than the short one in disyllables, 1.48 times in trisyllables and 1.3 times in four syllable words, all of these differences being statistically significant (SREDOJEVIĆ 2017c: 139). The author concludes that "quality distinctions between falling and rising accents are characterized by differences in the duration of the stressed vowel, as well as the differences in the duration of the stressed and the following vowel" (SREDojević 2017c: 216).

2.4. In her doctoral dissertation, Ana Batas researched the phonetic and accentual changes of words in continuous speech, based on the analysis of read texts (word lists, frame sentences and continuous read texts) (БАTAC 2014). The characteristics of accents are described based on the recordings of seven female and five male speakers, originating from various Neo Štokavian regions (including ekavian and ijekavian varieties), and had lived in Belgrade for at least one year and at most ten years prior to the study. The results of our research will be compared to those of Batas in relation to the general characteristics of accent, regardless of the speaker origin, and with the results of the analysis of her speakers originating from Vojvodina. ${ }^{18}$

2.4.1. Batas's findings reveal that the most frequent realization of words with long falling accent is that with a falling tonal tendency both on the stressed and the following vowel ${ }^{19}$, with a downward tendency between the two vowels (БАTAC 2014: 257). However, based on the numerical data provided in the tables, it can be seen that in a number of examples the post-stressed vowel begins at the same pitch where the previous one ended, and that in a considerable number of examples the ending of the stressed vowel is followed by an ascending tonal interval (БАТАС 2014: 264-265). In words with short falling accent, the most common realization is that with a rising-falling tonal slope on the stressed vowel, while the next vowel is always considerably lower-pitched (БАТАС 2014: 266). In the pronunciation of speakers of Vojvodina origin, in words with long rising accents the pitch on the stressed syllable at first falls, to be followed by an upward shift on the vowel in the following syllable (БАТАC 2014: 283). The data reported in the dissertation reveal that there is an approximately equal number of examples where $\mathrm{F} 0$ at the end of the stressed syllable is lower than F0 at its beginning and those where this is not the case. The author finds the same tonal direction in words with short rising accents.

\section{Research methods and techniques}

3.1. SPEAKERS. The total number of participants recorded for this research is 22, but for the purpose of this study we selected 14 speakers, 7 male and 7 female

${ }^{18}$ The author provides the data of F0 at the onset, peak and ending of the target vowels, but not the data on intensity or duration.

${ }^{19}$ When the stressed vowel is preceded by a sonorant, the vowel has a rising-falling tonal movement, with the slightly dominant rising part (БАТAC 2014: 264). Upon a closer inspection of the data provided in the table, it is noticeable that one third of the examples have higher F0 values at the ending of the stressed vowel than at its onset (БАТАC 2014: 276-278). 
(further marked as S1, S2.... S14), aged from 19 to 53 (mean age 37, stdev 11 years). All the speakers were born and lived in Novi Sad. Ten of the speakers are teachers at the Faculty of Philosophy in Novi Sad, seven of those being Serbian linguists, and four of the speakers were students ${ }^{20}$. All of them speak the ekavian variant of Standard Serbian. The typical pronunciation traits of some of them, in variable degrees, include the following: a) allophonic variations of vowels /e/ and /o/ are more markedly different depending on the degree of stress and quantity (cf. МАРкови - БЈЕЛАКОВић 2009б; MARкоVIĆ 2012) ; b) they may lack certain accentual alternations in nominal or adjectival declension and in verbal conjugation, with the limited distribution of long postaccentual prosodeme; c) the phonetic realizations of some accents are to a certain extent different from those recorded in other Neo Stokavian speeches. Although none of the traits listed are exclusively related to the speakers of Novi Sad origin, we believe that their joint usage and the degree in which they are exhibited make the speakers investigated, at least to some extent, recognizable among other speakers using the Standard Serbian norm.

The subjects were recorded in June and July 2019 in the studio at the Faculty of Philosophy in Novi Sad, with the expert help from the professional technician. The reverberation time in the studio is $0.3 \mathrm{~s}$, which guaranties the naturalness of recorded speech. The material was recorded digitally (sampling frequency: 44.1 kHz, resolution: 16 bit, software: Sound Forge 8.0, microphone: Neumann U-67). For the audiograms, we used the Audiopenguin software, and the acoustic analysis was performed using Praat (version 4.6.06, BOERSMA - WEENINK 2007).

Statistical analysis was performed by the Statistical Package for Social Sciences - SPSS 21. Numerical data were represented as mean values and variability measurements (range, standard deviation). The comparison of numerical values between two groups was performed by the non-parametric Mann-Whitney test, where the statistical significance was taken to be at $\mathrm{p}<0.05$.

3.2. CoRpus. The corpus analyzed for the purpose of this study included 832 realizations of 65 words, 45 of which were disyllabic, 18 trisyllabic and 4 quadrisyllabic. The words selected were minimal pairs with the same segmental content, differing only in the quality or quantity of the stressed target vowel. All the words were excerpted from the Dictionary of Standard Serbo-Croatian (Peyник срйскохрвайскойа књижевнои језика- PMC). The words were placed inside short declarative or imperative sentences. In the strict sense, some of the words analyzed are not true minimal pairs from the standpoint of the prosodic norm. The majority of the speakers pronounced long unstressed (posttonic) vowels consistently only after short rising accents, most frequently in medial syllables, somewhat less frequently in the final closed syllables and most rarely in the final open syllables. In the speech of our subjects long postaccentual vowels do not occur following falling or long rising accents ${ }^{21}$, after long posttonic vowels or after

${ }^{20}$ Among the 14 subjects there were 5 of those who took part in the recording used in the research SREDOJEVIĆ 2017c, where some of target words were also used for minimal pair analysis. However, the two studies used two different corpora, one of which was recorded in 2016, and the other in 2019.

${ }^{21}$ An exception to this are examples of several speakers of our study. 
short unstressed vowels. ${ }^{22}$ Taking this in consideration, we selected examples such as the present tense of the verb raditi (work) râdi $\left(3^{\text {rd }} \mathrm{p}\right.$. sg.) and the imperative form rádi $\left(2^{\text {nd }}\right.$ p. sg.), which act as minimal pairs in the speech of our subjects, although the prescribed norm distinguishes between the quantity of the unstressed vowels. The following words were analyzed:

cigarèta (cigarette, Nsg. f.), cigarétā (cigarette, Gpl. f.), dëla (act, Gsg. n.), dêla (part, Gsg m. (deo)), gòra (wood, Nsg f.), górā (wood, Gpl. f.), grâdu (city, Dsg. m.), [u] grádu ([in] city, Lsg. m.), hvâlīte (praise, pres. $2^{\text {nd }}$ p. pl.), hválite (praise, imper. $2^{\text {nd }}$ p. pl.), käpa (hat, Nsg f.), kâpā (hat, Gpl. f.), knjïga (book, Nsg. f.), knjîgā (book, Gpl. f.), kôsa (blackbird, Gsg. m.), Kósa (prop. n., Nsg. f.), kòsa (hair, Nsg. f.), kösa (oblique, adj. indef. Nsg. f.), kösi (oblique, adj. indef. Npl. m.), kòsi (hair, Dsg. f.), kòza (goat, Nsg. f.), kózā (goat, Gpl. f.), kräva (cow, Nsg. f.), krâvā (cow, Gpl. f.), kûpìte (buy, pres. $2^{\text {nd }}$ p. pl.), kúpite (buy, imper. $2^{\text {nd }}$ p. pl.), mlâda (bride, Nsg. f.), mláda (young, adj. indef. Nsg. f.), nösīte (carry, pres. $2^{\text {nd }}$ p. pl.), nòsite (carry, imper. $2^{\text {nd }}$ p. pl.), râda (work, Gsg. m.), Ráda (prop. n. Nsg. f.), râdī (work, pres. $3^{\text {rd }}$ p. sg.), rádi (work, imper. $2^{\text {nd }}$ p. sg.), râdìte (work, pres. $2^{\text {nd }}$ p. pl.), rádite (work, imper. $2^{\text {nd }}$ p. pl.), räna (wound, Nsg. f.), rânā (wound, Gpl. f.), sâdī (plant, pres. $3^{\text {rd }}$ p. sg.), sádi (plant, imper. $2^{\text {nd }}$ p. sg.), šârāte (draw, pres. $2^{\text {nd }}$ p. pl.), šárati (draw, inf.), sêna (hey, Gsg. n.), Séna (prop. n. Nsg. f.), sëna (shadow, Nsg. f.), slòmiti (break, inf.), slömìte (break, pres. $2^{\text {nd }}$ pl.), slöžìte (arrange, pres. $2^{\text {nd }} \mathrm{p} . \mathrm{pl}$.), slòzite (arrange, imper. $2^{\text {nd }} \mathrm{p} . \mathrm{pl}$.), sredina (environment, Nsg. f.), sredínā (environment, Gpl. f.), vòda (water, Nsg. f.), vódā (water, Gpl. f.), vödī (lead, pres. $3^{\text {rd }}$ p. sg.), vòdi (lead, imper. $2^{\text {nd }}$ p. sg.), vrâta (neck, Gsg. m.), vráta (door, Npl. t. n.), vrâtīte (return, pres. $2^{\text {nd }}$ p. pl.), vrátite (return, imper. 2. p. pl.), žäba (frog, Nsg. f.), žâbā (frog, Gpl. f.), žèna (woman, Nsg. f.), žénā (woman, Gpl. f.), žïca (wire, Nsg. f.), žìcā (wire, Gpl. f.).

The speakers read sentences from the screen, which was placed at their optimal distance. Each sentence was presented as a separate slide in PowerPoint, in order to avoid rising intonation typical when reading lists of sentences.

3.3. ACOUSTIC VARIABLES. The recorded material was analyzed for the following values of F0: at the onset and ending of the stressed syllable $\left(f O_{l o}, f O_{l e}\right)$ and at the onset and ending of the following syllable $\left(f 0_{2 o}, f O_{2 e}\right)$, maximal F0 values of both vowels $\left(f 0_{1 \max }, f 0_{2 \max }\right)$, and the values were expressed in Hertz [Hz]. In order to enable reliable comparison of results obtained from different speakers ('T HART et al. 2006: 24), on the basis of the abovementioned parameters and the formula $R=\left(12 \log _{10}\left(f 0_{\max } / f 0_{\text {min }}\right)\right) / \log _{10} 2$ (BAKEN - ORLIKOFF 2000: 148), we calculated the range between the initial and final values of $\mathrm{f} 0$ of the stressed vowel $-R\left(f 0_{l o}-f 0_{l e}\right)$, the range between the tonal peaks of the stressed and the following vowel $R\left(f O_{1 \max }-f O_{2 \max }\right)$, and the range between the ending of the stressed and the onset of the following vowel $-R\left(f 0_{1 e}-f 0_{20}\right)$. Those values were expressed in semitones [ST]. Measurements of intensity involved the values of the stressed and the following vowel $(I 1, I 2)$, and the difference between the two $(I 1-I 2)$. These values are expressed in decibels [dB]. Quantitative measurements involved the duration of

${ }^{22}$ These findings are in line with previous studies of Novi Sad speech, where the subjects were also educated speakers of Novi Sad background (МАрковић - БЈелАКовић 2009а: 142; СРедолевић 2009б: 230-231; СРедолевић - Суботић 2011: 122; SREdojević 2013: 221-223; 2017c: 147-148). 
the stressed and the following vowel $(t 1, t 2)$, expressed in milliseconds [ms]. Since speech tempo was variable, we normalized the measurements of duration in order to be able to compare vowel durations in different phrases objectively. We did this by counting speech tempo for every speaker $(T)$, i.e. the speed of delivery, as the ratio between the number of syllables [syl] in the phrase and the duration of the phrase, expressed in seconds [s]. Based on the values of tempo of each phrase, we calculated the mean tempo of each speaker $(\mathrm{Tm})$. Vowel duration was normalized as $\mathrm{x}\left(t x_{n o r m}\right)$ by using the formula: $t x_{n o r m}=(T m / T x) * t x$. We also calculated the duration from the onset of the stressed vowel up to its tonal peak $\left(t 1_{\max }\right)$, which was subsequently represented in relation to the total duration of the stressed syllable $\left(t 1_{\max } \%\right)$ and expressed as percentages. The duration of the vowel following the stressed one is expressed in relation to the total duration of the stressed vowel ( $t 2$ $(\% t 1))$ and is also expressed as percentages.

\section{Results AND Discussion}

4.1. Minimal pairs of words with long accents in most cases have a falling tonal slope on the stressed vowel. In words with long falling accent the falling slope is consistently found in $69 \%$ of disyllabic and $53 \%$ of trisyllabic words, while in the other cases it is rising-falling, more frequently with the dominant falling interval (the tonal peak being on the first half of the vowel). In words with long rising accent, pure falling slope was found on $80 \%$ of disyllabic and trisyllabic words, while pure rise was present in $12 \%$ of disyllabic and $5 \%$ of trisyllabic words (produced only by two of the subjects). In long falling accents more than $90 \%$ of words have higher F0 on the stressed vowel ending than at the onset of the following vowel, ${ }^{23}$ while all the words with long rising accents exhibit the opposite tendency. Tonal relation between the stressed and the following vowel is falling in words with long falling accents, and rising in those with long rising accents (cf. Figures 1 and 2) ${ }^{24}$. This is manifested in the F0 range between the F0 peaks of the stressed and the following vowel, ${ }^{25}$ and even more markedly in the F0 range between the ending of the stressed and the onset of the following vowel. The vowel following the stressed one has consistently falling or rising-falling tonal slope, but the falling interval is more dominant in most words with long falling accents, while with rising accents, the rising part is more dominant. In words with long falling accents the difference in intensity between the stressed and the following vowel is greater than $1 \mathrm{~dB}$, which means that the stressed vowel is perceptively louder. In words with long rising accent, the stressed syllable is louder in $62 \%$ of disyllabic and $59 \%$ of trisyllabic words, while in $28 \%$ of disyllabic and trisyllabic words the stressed and

${ }^{23}$ In the rest of the cases, F0 at the onset of the unstressed vowel may be slightly higher than at the ending of the stressed vowel, but in those cases the stressed vowels have markedly falling tonal slopes, and the ascending tonal interval between the two is small.

${ }^{24}$ The figures represent the waveform (in the upper part) and F0 lines (in the bottom part). The symbols used in transcriptions are the symbols of the International Phonetic Alphabet (HIPA 2007).

${ }^{25}$ Yet, it should be noted that in $18 \%$ of words with long rising accent the F0 peak of the stressed vowel is more dominant than the F0 peak of the vowel in the following syllable. Although in these examples the stressed vowel has a conspicuos falling slope, with a great ascending interval between the stressed and the following vowel, the F0 peak of the unstressed vowel still does not reach the values of F0 reached in the stressed vowel. 
the following vowel are of perceived as equally loud. In terms of quantity, long stressed vowels with falling and rising accents tend to be, on average, of the same duration.

4.2. Minimal pairs of words with short accents also tend to have a falling F0 slope on the stressed vowel. In words with short falling accent pure falling slope is found in $50 \%$ of disyllabic and $41 \%$ of trisyllabic words, while in $16 \%$ of disyllables and $21 \%$ of trisyllables the tonal slope is consistently rising. The rest of the words were produced with a rising-falling slope, with an approximately even number of cases with the dominant falling or rising interval (in the latter case, the F0 peak is on the second half of the vowel). Words with short rising accent most commonly have a falling tonal slope on the stressed syllable. Among the minimal pairs of words with short accents the distinction between accent types is clearly made by the tonal relation between the stressed and the following vowel, where it is descending in words with short falling accent, and ascending in words with short rising accent. This is consistently shown by the range of F0 between the peaks of F0 of the stressed and the following vowel, ${ }^{26}$ as well as the F0 range between the ending of the stressed and the onset of the following vowel (cf. Figures 3 and 4). The vowel following the stressed one has a pure falling or rising-falling tonal slope, with the dominant falling interval in all the words with short falling accent analyzed. In words with short rising accent, $30 \%$ of all examples have a rising-falling tonal slope with the more dominant rising part. In all the words with short falling accent, the difference in intensity of the stressed and the following vowel is over $1 \mathrm{~dB}$. In words with short rising accent, the stressed vowel is louder in $60 \%$ of disyllables and $78 \%$ of trisyllables, while the perceptual loudness of the two vowels is equal in $31 \%$ of disyllables and $11 \%$ trisyllables. The duration of the short stressed vowels is approximately the same with both accent types.

4.3. The description of the measurements of tone, intensity and duration was used as the basis of general characteristics of the four accents in Serbian. In order to establish whether the observed parameters are phonologically relevant for establishing qualitative distinction, we tested whether these values differed significantly between the members of minimal pairs of words. The results reveal that in terms of $\mathrm{fO}_{10}$ (pitch height at the onset of the stressed vowel) there are statistically significant differences among the words with long accents, but not among those with short accents (Tables 1 and 2 , parameter $\mathrm{f}_{10}$ ). This clearly indicates that this parameter cannot be phonologically relevant for establishing qualitative distinctions. The mean values of F0 range between the onset and ending of the stressed vowel are significantly different among the words with long and short accents (Tables 1 and 2, parameter $\mathrm{R}\left(\mathrm{fO}_{10}-\mathrm{fO}_{1 \mathrm{e}}\right)$ ). The mean values of this parameter indicate that both long and short accents most frequently have the same direction of tonal trajectory (falling slope), and the minimal pairs of long and short accents differ in terms of the size of this falling interval. However, since pure

${ }^{26}$ In $7 \%$ of words with short rising accent the stressed vowel has a higher F0 peak than the vowel in the following syllable. As was the case with some words with long rising accent, the stressed vowel in these examples has markedly falling tonal slope with considerable descending interval, with a great ascending interval to the unstressed vowel. Still, the tonal peak of the unstressed vowel does not reach the F0 values of the stressed syllable. 
falling or rising falling slopes with the more dominant falling intervals are found in both accent types, this parameter clearly cannot be used as the basis of quality distinction either in long or short accents. For the same reason, the position of the tonal peak, which also differs statistically among long and short accents (Tables 1 and 2, parameter $\mathrm{t} 1_{\max \%}$ ), cannot be taken as a significant indicator of accent quality.

The mean values of the parameters concerning the tonal relation between the stressed and the following vowel are significantly different among words with long and short accents (Tables 1 and 2, parametres $\mathrm{R}\left(\mathrm{fO}_{1 \mathrm{e}}-\mathrm{fO}_{2 \mathrm{o}}\right)$ and $\mathrm{R}\left(\mathrm{fO}_{1 \max }-\mathrm{fO}_{2 \max }\right)$ ). Out of the two parameters, the range of F0 among the ending of the stressed and the onset of the following vowel more consistently distinguishes between falling and rising accent both with long and short accents, and is therefore relevant for establishing the phonological distinction. We should note here that the downward shift is found between the ending of the stressed and the following vowel only in words with falling accents. An upward shift is found in all words with rising accents. Only in few examples of words with falling accents a small degree of upward shift was found between the stressed and the following vowel, but the stressed vowel of these words is characterized by a steeper falling slope. ${ }^{27}$

The mean differences in intensity of the stressed and the following vowel are significantly different in minimal pairs both in long and short accents (Tables 1 and 2, parameter I1 - I2), but since the descending intensity relation between the stressed and the following syllable is not solely found in words with falling accent, it is clearly only a subsidiary feature of accent quality. The differences in the mean duration values between falling and rising accents, both long and short, are not significantly different (Tables 1 and 2 , parameters $t 1_{\text {norm }}$ ).

Table 1: Comparison of parameters F0, intensity and duration between minimal pairs with long accents ${ }^{28}$

\begin{tabular}{|c|c|c|c|c|c|c|}
\hline Parameter & Accent & $\mathrm{N}$ & $\overline{\mathrm{X}}$ & SD & $\begin{array}{c}\text { Mann-Whitney test } \\
\text { U }\end{array}$ & $\mathrm{p}$ \\
\hline \multirow{2}{*}{$\mathrm{fO}_{1 \mathrm{o}}$} & LF & 168 & 177 & 48,29 & \multirow{2}{*}{10935,500} & \multirow{2}{*}{$\mathbf{0 , 0 0 0}$} \\
\hline & LR & 167 & 160 & 46,47 & & \\
\hline \multirow{2}{*}{$\mathrm{R}\left(\mathrm{fO}_{1 \mathrm{o}}-\mathrm{f0}_{1 \mathrm{e}}\right)$} & LF & 168 & $-2,89$ & 2,08 & \multirow{2}{*}{9140,000} & \multirow{2}{*}{$\mathbf{0 , 0 0 0}$} \\
\hline & LR & 167 & $-1,68$ & 1,58 & & \\
\hline \multirow{2}{*}{$R\left(\mathrm{f0}_{1 \text { max }}-\mathrm{f0}_{2 \text { max }}\right)$} & LF & 168 & $-4,17$ & 2,50 & \multirow{2}{*}{382,000} & \multirow{2}{*}{$\mathbf{0 , 0 0 0}$} \\
\hline & LR & 167 & 1,29 & 1,63 & & \\
\hline \multirow{2}{*}{$\mathrm{R}\left(\mathrm{fO}_{1 \mathrm{e}}-\mathrm{fO}_{2 \mathrm{o}}\right)$} & LF & 168 & $-1,24$ & 1,74 & \multirow{2}{*}{337,000} & \multirow{2}{*}{$\mathbf{0 , 0 0 0}$} \\
\hline & LR & 167 & 2,54 & 1,51 & & \\
\hline \multirow{2}{*}{$\mathrm{t} 1_{\max \%}$} & LF & 168 & 16 & 26,19 & \multirow{2}{*}{12047,000} & \multirow{2}{*}{0,005} \\
\hline & LR & 167 & 13 & 31,88 & & \\
\hline
\end{tabular}

${ }^{27}$ It is our opinion that markedly rising or falling tonal slope on the stressed syllable might be a sufficient phonetic signal for the perception of accent quality, while in all other cases, the primary signal is the tonal relation between the ending of the stressed and the onset of the following vowel. However, this can only be proved after detailed research into perception of accents.

${ }^{28}$ The data given in Tables $1,2,3$ and 4 represent $-(N)$ number of cases, mean value $(\overline{\mathrm{X}})$, standard deviation (SD), Mann-Whitney test results (U), and $p$ level of significance. The values which are statistically significant $(\mathrm{p}<0,05)$ are marked in bold script. 


\begin{tabular}{|c|c|c|c|c|c|c|}
\hline \multirow{2}{*}{$\mathrm{I} 1-\mathrm{I} 2$} & LF & 168 & 7,21 & 3,37 & \multirow{2}{*}{3302,000} & \multirow{2}{*}{0,000} \\
\hline & LR & 167 & 2,08 & 2,92 & & \\
\hline \multirow{2}{*}{$\mathrm{t} 1_{\text {norm }}$} & LF & 168 & 160 & 37,77 & \multirow{2}{*}{13954,000} & \multirow{2}{*}{0,933} \\
\hline & LR & 167 & 159 & 42,30 & & \\
\hline
\end{tabular}

Table 2: Comparison of parameters F0, intensity and duration between minimal pairs with short accents

\begin{tabular}{|c|c|c|c|c|c|c|}
\hline Parameter & Accent & $\mathrm{N}$ & $\bar{X}$ & SD & $\begin{array}{c}\text { Mann-Whitney test } \\
\text { U }\end{array}$ & $\mathrm{p}$ \\
\hline \multirow{2}{*}{$\mathrm{fO}_{1 \mathrm{o}}$} & SF & 72 & 168 & 41,09 & \multirow{2}{*}{2228,000} & \multirow{2}{*}{0,233} \\
\hline & SR & 70 & 162 & 40,78 & & \\
\hline \multirow{2}{*}{$\mathrm{R}\left(\mathrm{fO}_{\mathrm{lo}}-\mathrm{f0}_{\mathrm{le}}\right)$} & SF & 72 & $-0,20$ & 1,33 & \multirow{2}{*}{1269,000} & \multirow{2}{*}{0,000} \\
\hline & SR & 70 & $-1,41$ & 1,24 & & \\
\hline \multirow{2}{*}{$\mathrm{R}\left(\mathrm{fO}_{1 \max }-\mathrm{f0}_{2 \max }\right)$} & $\mathrm{SF}$ & 72 & $-2,63$ & 1,85 & \multirow{2}{*}{37,00} & \multirow{2}{*}{0,000} \\
\hline & SR & 70 & 2,13 & 1,58 & & \\
\hline \multirow{2}{*}{$\mathrm{R}\left(\mathrm{fO}_{1 \mathrm{e}}-\mathrm{f0}_{2 \mathrm{o}}\right)$} & $\mathrm{SF}$ & 72 & $-1,84$ & 1,73 & \multirow{2}{*}{4,000} & \multirow{2}{*}{$\mathbf{0 , 0 0 0}$} \\
\hline & SR & 70 & 3,22 & 1,55 & & \\
\hline \multirow{2}{*}{$\mathrm{t} 1_{\max \%}$} & SF & 72 & 46 & 43,51 & \multirow{2}{*}{1548,500} & \multirow{2}{*}{$\mathbf{0 , 0 0 0}$} \\
\hline & SR & 70 & 12 & 31,11 & & \\
\hline \multirow{2}{*}{ I1 - I2 } & $\mathrm{SF}$ & 72 & 6,98 & 2,73 & \multirow{2}{*}{447,500} & \multirow{2}{*}{0,000} \\
\hline & SR & 70 & 2,14 & 2,48 & & \\
\hline \multirow{2}{*}{$\mathrm{t} 1_{\text {norm }}$} & $\mathrm{SF}$ & 72 & 119 & 23,60 & \multirow{2}{*}{2145,000} & \multirow{2}{*}{0,126} \\
\hline & SR & 70 & 112 & 24,10 & & \\
\hline
\end{tabular}

Table 3: Comparison of duration of the stressed and the following vowel in minimal pairs with falling accents

\begin{tabular}{|c|c|c|c|c|c|c|}
\hline Parameter & Accent & $\mathrm{N}$ & $\bar{X}$ & SD & $\begin{array}{c}\text { Mann-Whitney test } \\
\text { U }\end{array}$ & $\mathrm{p}$ \\
\hline \multirow{2}{*}{$\mathrm{t} 1_{\text {norm }}$} & LF & 120 & 157 & 37,69 & \multirow{2}{*}{3328,000} & \multirow{2}{*}{0,000} \\
\hline & SF & 118 & 122 & 32,03 & & \\
\hline \multirow{2}{*}{$\mathrm{t} 2_{\text {norm }}$} & LF & 120 & 60 & 18,74 & \multirow{2}{*}{6191,000} & \multirow{2}{*}{0,094} \\
\hline & SF & 118 & 56 & 15,49 & & \\
\hline \multirow{2}{*}{$\mathrm{t} 2(\% \mathrm{t} 1)$} & LF & 120 & 39 & 9,21 & \multirow{2}{*}{4097,500} & \multirow{2}{*}{0,000} \\
\hline & SF & 118 & 47 & 12,81 & & \\
\hline
\end{tabular}

Table 4: Comparison of duration of the stressed and the following vowel in minimal pairs with rising accents

\begin{tabular}{|c|c|c|c|c|c|c|}
\hline Parameter & Accent & $\mathrm{N}$ & $\overline{\mathrm{X}}$ & SD & $\begin{array}{c}\text { Mann-Whitney test } \\
U\end{array}$ & $\mathrm{p}$ \\
\hline \multirow{2}{*}{$\mathrm{t} 1_{\text {norm }}$} & LR & 79 & 155 & 31,15 & \multirow{2}{*}{1014,000} & \multirow{2}{*}{0,000} \\
\hline & SR & 80 & 115 & 29,52 & & \\
\hline \multirow{2}{*}{$\mathrm{t} 2_{\text {norm }}$} & LR & 79 & 72 & 22,28 & \multirow{2}{*}{2121,000} & \multirow{2}{*}{0,000} \\
\hline & SR & 80 & 61 & 17,02 & & \\
\hline \multirow{2}{*}{$\mathrm{t} 2(\% \mathrm{t} 1)$} & LR & 79 & 47 & 12,15 & \multirow{2}{*}{2321,000} & \multirow{2}{*}{$\mathbf{0 , 0 0}$} \\
\hline & SR & 80 & 54 & 17,12 & & \\
\hline
\end{tabular}


4.4. Among the minimal pairs of words with falling accents, phonologically long and short vowels differ in duration, the long one being 1.28 times longer than the short vowel, and this difference is statistically significant (Table 3, parameter $\left.\mathrm{t} 1_{\text {norm }}\right) \cdot{ }^{29}$ In minimal pairs with rising accents, phonologically long vowels are also longer in duration than the phonologically short ones, 1.38 times on average, the difference being statistically significant (Table 4 , parameter $\mathrm{t}_{\text {norm }}$ ) ${ }^{30}$

Minimal pairs of words with falling and rising accents differ in terms of the duration of the first posttonic unstressed vowel, but these data are not consistent. In absolute values, unstressed vowels in words with long accents have longer duration than those with short accents of the same quality. However, with falling accents this difference is not statistically significant, while with rising ones it is (Tables 3 and 4 , parameter $t 2_{\text {norm }}$ ). If we express the duration of the unstressed vowel as the percentage of the preceding stressed one, the results show that it takes up 39\% of the duration in words with long falling accent, and $47 \%$ in words with short falling accent. On the other hand, with long rising accent the unstressed vowel takes up $47 \%$ of the stressed one, and $54 \%$ in words with short rising accent. From this point of view, the mean duration of unstressed vowels is significantly different in pairs of words with accents of the same quality (Tables 3 and 4, parameter $\mathrm{t} 2(\% \mathrm{t} 1))$. This means that among the words with falling and rising accents the contrast between the stressed and the following vowel is more marked in words with long than with short accents. A larger difference in duration between the stressed and the following vowel is an additional perceptual marker of long accents.

4.5. As can be seen from our results, the typical realizations of long and short falling accents in our corpus are similar to those described by Ivić and Lehiste based on the speech of Pavle Ivić and 12 additional speakers. However, the most frequent realizations of long rising accent in our corpus of minimal pairs are different from those recorded by Pavle Ivić and some of the speakers from his additional test group. The main difference is in the tonal movement on the stressed vowel, which was characterized by a falling tonal slope in 12 of our participants (rising slope being produced only by two of the participants), while in Ivić and Lehiste's corpus it shows rising tonal slopes in this context. Our findings point to other differences as well. The tonal interval between the stressed and the following vowel in our corpus is rather prominent and always realized as an upward shift in long rising accents. On the other hand, in Ivić and Lehiste's corpus it is not always ascending, and when it is, the range of the shift is less marked than in our speakers' speech. The realizations of short rising accents in our corpus of minimal pairs are different from those typical of Ivić's speech, but not from the speech of his additional group of speakers.

The description of the realizations of accents in our corpus of minimal pairs is partly comparable to the descriptions by Jokanović-Mihajlov. The tonal movement in words with falling accents described in our corpus was also reported in the findings of Jokanović-Mihajlov for speakers of Vojvodina background. However, falling tonal slope on the stressed vowel, which was the dominant tonal

${ }^{29}$ Compare the duration of vowels and similarity of tonal slopes in Figures 5 and 6 .

${ }^{30}$ Compare the duration of vowels and similarity of tonal slopes in Figures 7 and 8 . 
direction of rising accents in our recorded corpus, was only reported in words with short rising accents by Jokanović-Mihajlov for speakers from Vojvodina, and not in long rising accents.

The description of accents in our corpus of minimal pairs is in accordance with the descriptions in the studies SREDOJEvić 2015a; 2016; 2017c.

The realizations of falling accents in our corpus of minimal pairs are similar to the realizations described by Batas, but the results regarding rising accents are different.

4.6. The description of intensity relations between the stressed and the following vowel in our minimal pair corpus is generally in line with the descriptions provided by Ivić and Lehiste, ${ }^{31}$ and is completely in accordance with the studies SREDOJEVIĆ 2015a; 2016; 2017c.

4.7. In our research of minimal pair corpus the differences in the duration of vowels with falling accents and with rising accents are less marked than in the typical examples reported in Ивић - Лехисте 2002 and SREDojević 2017c.

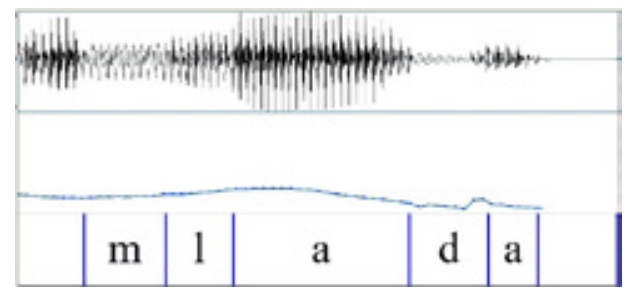

Figure 1: mlâda (The bride is singing to the wedding procession) $(\mathrm{G} 1)^{31}$

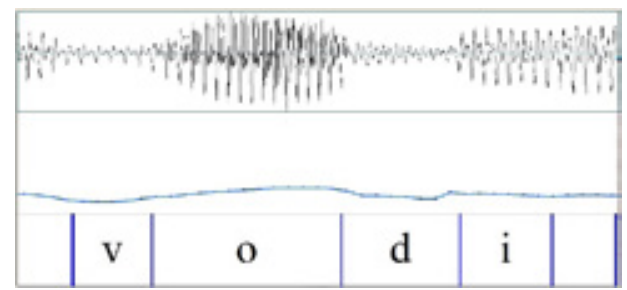

Figure 3: vödı̆ (He's taking the children out) $(\mathrm{G} 6)^{33}$

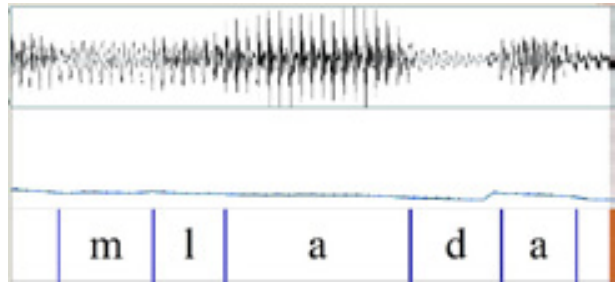

Figure 2: mláda (Tanja is a young woman) $(\mathrm{G} 1)^{32}$

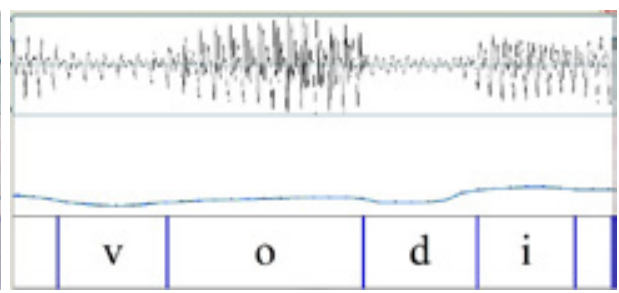

Figure 4: vòdi (Take the children outside!) $(\mathrm{G} 6)^{34}$ applied.

${ }^{31}$ The comparison of our results is not possible due to differences in research methodologies ${ }^{32}$ [a]: $\mathrm{f0}_{\mathrm{o}}=129 \mathrm{~Hz} ; \mathrm{f0}_{\max }=130 \mathrm{~Hz} ; \mathrm{f0}_{\mathrm{e}}=99 \mathrm{~Hz} ; \mathrm{I}=76.01 \mathrm{~dB} ; \mathrm{t}=186 \mathrm{~ms}$.

[a]: $\mathrm{fO}_{\mathrm{o}}=95 \mathrm{~Hz}$; $\mathrm{fO}_{\max }=95 \mathrm{~Hz} ; \mathrm{fO}_{\mathrm{e}}=86 \mathrm{~Hz} ; \mathrm{I}=66.36 \mathrm{~dB} ; \mathrm{t}=53 \mathrm{~ms}$.

${ }^{33}$ [a]: $\mathrm{fO}_{\mathrm{o}}=108 \mathrm{~Hz}$; f0 $\max =108 \mathrm{~Hz} ; \mathrm{fO}_{\mathrm{e}}=100 \mathrm{~Hz} ; \mathrm{I}=74.71 \mathrm{~dB} ; \mathrm{t}=162 \mathrm{~ms}$.

[a]: $\mathrm{f0}_{\mathrm{o}}=109 \mathrm{~Hz} ; \mathrm{f0}_{\max }=109 \mathrm{~Hz} ; \mathrm{f0}_{\mathrm{e}}=103 \mathrm{~Hz} ; \mathrm{I}=72.26 \mathrm{~dB} ; \mathrm{t}=55 \mathrm{~ms}$.

34 [o]: $\mathrm{fO}_{\mathrm{o}}=113 \mathrm{~Hz}$; f0 $\mathrm{max}_{\max }=132 \mathrm{~Hz} ; \mathrm{fO}_{\mathrm{e}}=129 \mathrm{~Hz} ; \mathrm{I}=77.94 \mathrm{~dB} ; \mathrm{t}=119 \mathrm{~ms}$.

[i]: $\mathrm{fO}_{\mathrm{o}}=119 \mathrm{~Hz} ; \mathrm{f0}_{\max }=119 \mathrm{~Hz} ; \mathrm{f0}_{\mathrm{e}}=112 \mathrm{~Hz} ; \mathrm{I}=75.39 \mathrm{~dB} ; \mathrm{t}=61 \mathrm{~ms}$.

${ }^{35}$ [o]: $\mathrm{f0}_{\mathrm{o}}=105 \mathrm{~Hz} ; \mathrm{fO}_{\max }=117 \mathrm{~Hz} ; \mathrm{fO}_{\mathrm{e}}=114 \mathrm{~Hz} ; \mathrm{I}=78.28 \mathrm{~dB} ; \mathrm{t}=115 \mathrm{~ms}$.

[i]: $\mathrm{fO}_{\mathrm{o}}=134 \mathrm{~Hz} ; \mathrm{f0}_{\max }=140 \mathrm{~Hz} ; \mathrm{fO}_{\mathrm{e}}=136 \mathrm{~Hz} ; \mathrm{I}=77.01 \mathrm{~dB} ; \mathrm{t}=58 \mathrm{~ms}$. 


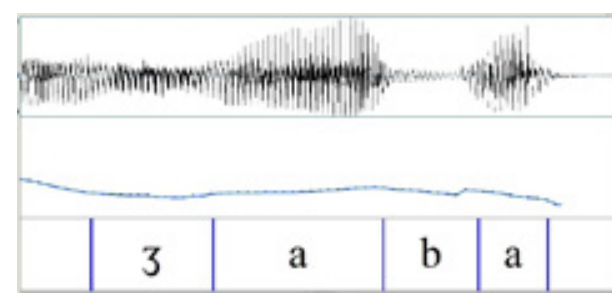

Figure 5: žäba (The green frog is croaking.) $(\mathrm{G} 12)^{35}$

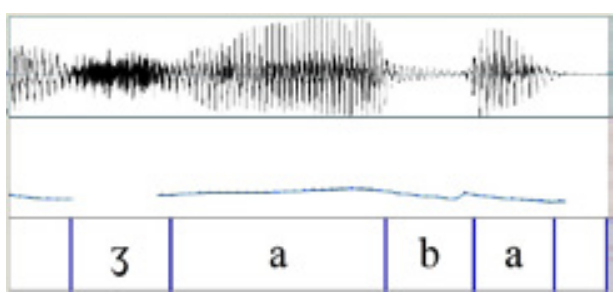

Figure 6: žâbă (Many frogs are croaking) $(\mathrm{G} 12)^{36}$

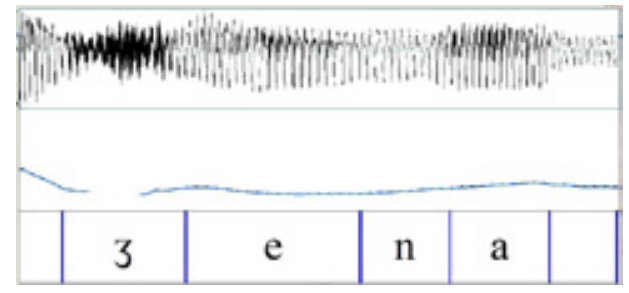

Figure 7: žèna (His wife is coming) $(\mathrm{G} 5)^{37}$

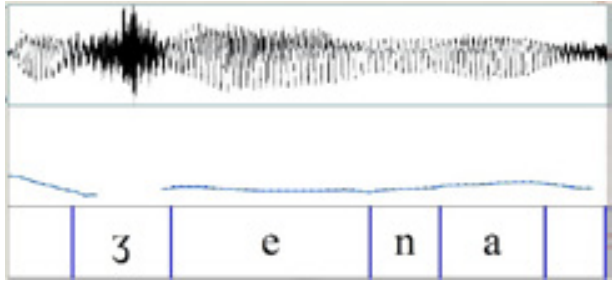

Figure 8: žénă (We benefit from such women) $(\mathrm{G} 5)^{38}$

5. ConCLuSION. Our analysis of the largest corpus of minimal pairs in Standard Serbian so far, recorded by educated speakers of Novi Sad background, reveals that quality distinctions between accents are founded on the tonal relation between the stressed and the following vowel. In falling accents this relation is descending, and in rising accents it is ascending. This conclusion was reached in the research by Pavle Ivić and Ilse Lehiste, as well as Jelica Jokanović-Mihajlov, although these authors did not precisely state on the basis of which parameters they defined the relation as falling or rising. On the other hand, the results of our research clearly point that the quality distinctions are most reliably reflected by F0 range between the ending of the stressed and the beginning of the next vowel, comparable to the results reported in SREDOJEVIĆ 2015a; 2016; 2017c. Our results do not support Ivić and Lehiste's claim that tonal shift on the stressed vowel may be distinctive in words with long accents, nor the phonological view of rising accents as disyllabic in the sense implied by Ivić and Lehiste, as well as other researchers, following Masing's ideas. In terms of the mean values of the parameters such as the F0 range between the onset and ending of the stressed vowel, between tonal peaks of the stressed and the following vowel, as well as the difference in intensity of the two subsequent vowels, our research shows that there are statistically significant distinguishers among the pairs of falling and rising accents, although

\footnotetext{
${ }^{36}[\mathrm{a}]: \mathrm{f0}_{\mathrm{o}}=199 \mathrm{~Hz} ; \mathrm{f0}_{\max }=224 \mathrm{~Hz} ; \mathrm{f0}_{\mathrm{e}}=224 \mathrm{~Hz} ; \mathrm{I}=72.66 \mathrm{~dB} ; \mathrm{t}=131 \mathrm{~ms}$. [a]: f0 $0_{\mathrm{o}}=210 \mathrm{~Hz} ; \mathrm{fO}_{\max }=210 \mathrm{~Hz} ; \mathrm{f0}_{\mathrm{e}}=177 \mathrm{~Hz} ; \mathrm{I}=71.96 \mathrm{~dB} ; \mathrm{t}=56 \mathrm{~ms}$. 37 [a]: $\mathrm{f0}_{\mathrm{o}}=196 \mathrm{~Hz} ; \mathrm{f0}_{\max }=216 \mathrm{~Hz} ; \mathrm{f0}_{\mathrm{e}}=208 \mathrm{~Hz} ; \mathrm{I}=71.26 \mathrm{~dB} ; \mathrm{t}=159 \mathrm{~ms}$. [a]: f0 $0_{\mathrm{o}}=191 \mathrm{~Hz} ; \mathrm{f0}_{\max }=191 \mathrm{~Hz} ; \mathrm{f0}_{\mathrm{e}}=163 \mathrm{~Hz} ; \mathrm{I}=69.03 \mathrm{~dB} ; \mathrm{t}=62 \mathrm{~ms}$. 38 [e]: $\mathrm{fO}_{\mathrm{o}}=188 \mathrm{~Hz} ; \mathrm{fO}_{\max }=193 \mathrm{~Hz} ; \mathrm{fO}_{\mathrm{e}}=165 \mathrm{~Hz} ; \mathrm{I}=75.19 \mathrm{~dB} ; \mathrm{t}=126 \mathrm{~ms}$. [a]: $\mathrm{fO}_{\mathrm{o}}=186 \mathrm{~Hz} ; \mathrm{fO}_{\max }=210 \mathrm{~Hz} ; \mathrm{fO}_{\mathrm{e}}=210 \mathrm{~Hz} ; \mathrm{I}=75.09 \mathrm{~dB} ; \mathrm{t}=86 \mathrm{~ms}$. 39 [e]: $\mathrm{fO}_{\mathrm{o}}=174 \mathrm{~Hz} ; \mathrm{fO}_{\max }=174 \mathrm{~Hz} ; \mathrm{fO}_{\mathrm{e}}=159 \mathrm{~Hz} ; \mathrm{I}=74.42 \mathrm{~dB} ; \mathrm{t}=153 \mathrm{~ms}$. [a]: f0 $0_{\mathrm{o}}=180 \mathrm{~Hz} ; \mathrm{fO}_{\max }=195 \mathrm{~Hz} ; \mathrm{fO}_{\mathrm{e}}=192 \mathrm{~Hz} ; \mathrm{I}=72.31 \mathrm{~dB} ; \mathrm{t}=84 \mathrm{~ms}$.
} 
some of the differences are subsidiary rather than distinctive features. Quantity distinctions between pairs of falling and rising accents are based on the difference of stressed vowels, since the long stressed vowel with a falling accent is on average 1.28 times longer than the short one, and in words with rising accents the long stressed vowel is on average 1.38 times longer than the short one. Quantity distinctions are partly based on the differences in duration of the stressed and the following vowel.

Since the goal of this study was to give a detailed phonetic analysis of word accents in one dialect of Serbian, that spoken in the city of Novi Sad, we believe that it raises new and intriguiging questions about the phonetic nature of word accents in other dialects of Serbian as well, which seems like a worthwile subject of future investigation.

\section{REFERENCES}

Boersma, Paul, David WeEnink. Praat: Doing Phonetics by Computer (Version 6.1.03) [Computer Program] <http://www.praat.org> 28. 6. 2017.

Flanagan, J. L. Estimates of the Maximum Precision Necessary in Quantizing Certain 'Dimensions' of Vowel Sounds. The Journal of the Acoustical Society of America 29 (1957): 533-534.

HIPA: Handbook of the International Phonetic Association: A Guide to the Use of the International Phonetic Alphabet. International Phonetic Association (ed.). Cambridge University Press, 2007.

Leniste, Ilse. Suprasegmentals $\left[2^{\text {nd }}\right.$ printing]. Cambridge - Massachusetts - London: The M. I. T. Press, 1977.

MARKović, Maja. Uporedna proučavanja vokala engleskog $i$ srpskog jezika: između univerzalnog $i$ specifičnog. Novi Sad: Filozofski fakultet, Odsek za anglistiku, 2012.

Masing, Leonhard. Die Hauptformen des serbisch-chorwatischen Accents: nebst einleitenden Bemerkungen zur Accentlehre insbesondere des Griechischen und des Sanskrit: Inauguraldissertation, zur Erlangung des philosophischen Doktorgrades verfasst und der hohen philosophischen Facultät an der Universität zu Leipzig eingereicht von Leonhard Masing. Mémoires de l'Académie Impériale des Sciences de St.-Pétersbourg. Ser. 7 ; T. 23, N 5, 1876. [doktorska disertacija].

Pletikos, Elenmari. Akustički opis hrvatske prozodije riječi (Prozodija riječi u suvremenom općem naddijalektalnom govoru). Zagreb: Filozofski fakultet, 2008. [doktorska disertacija].

SREDOJEVIĆ, Dejan. Neakcentovane dužine i jezik medija. Vesna Krčmar (ur.). Zbornik radova Akademije umetnosti 1 (2013): 205-224.

SREDOJeVIĆ, Dejan. Eksperimentalno-fonetsko ispitivanje distinkcija između dugosilaznog i dugouzlaznog akcenta u novosadskom govoru. Снежана Гудурић, Марија Стефановић (ур.). Језиии и кулииуре у времену и йростйору IV/2. Нови Сад: Филозофски факултет, 2015a, 335-342.

SREDOJEVIĆ, Dejan. Kratkouzlazni akcenat u govoru studenata žurnalistike poreklom iz nečetvoroakcenatskih oblasti. Dejan Pralica, Norbert Šinković (ur.). Digitalne medijske tehnologije i društveno-obrazovne promene 5. Novi Sad: Filozofski fakultet, 2015b, 235-246.

SREDOJEVIĆ, Dejan. Fonološki značaj različitih fonetskih karakteristika pri uspostavljanju distinkcije kvaliteta između kratkih akcenata u pojedinim govorima Srema, Banata i Вačke. Јасмина Дражић, Исидора Бјелаковић, Дејан Средојевић (ур.). Теме језикословне у србистиици кроз gијахронију и синхронију. Зборник у части Љиљани Суботиић. Нови Сад: Филозофски факултет, 2016, 279-292.

SRedoJević, Dejan. How Much Do Phonetic Realisations of Serbian Accents Actually Differ from Each

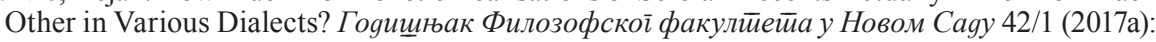
323-337.

SREDOJEVIĆ, Dejan. Fonetske razlike između fonološki istih akcenata u različitim vojvođanskim govorima. Снежана Гудурић, Биљана Радић-Бојанић (ур.). Језици и кулииуре у времену и йроc̄̄̄opy VI. Нови Сад: Филозофски факултет, 2017b, 185-197. 
SREDOJEVIĆ, Dejan. Fonetsko-fonološki opis akcenata u standardnom srpskom jeziku-od specifičnog ka opštem. Novi Sad: Filozofski fakultet, 2017c.

SREDOJEvić, Dejan. O razlikama između tipova fonetskih realizacija dugouzlaznog akcenta. Гоguщuґak Филозофской факулиеетиа у Новом Саяу 45/1 (2020): 275-290.

Sredojević, Dejan, Ljiljana Subotić. The Neo-Stokavian Accent Shift and the Phonological Significance of Suprasegmental Features in Different Štokavian Dialects. Acoustic and Phonetic Analysis. Bonifacas Stundžia (ed.). Baltistica. Priedas VII. Vilniaus: Vilniaus universitetas, 2011, 227-242.

'T Hart, Johan, René Collier, Antonie Cohen. A Perceptual Study of Intonation: an Experimental-Phonetic Approach to Speech Melody. Cambridge University Press, 2006.

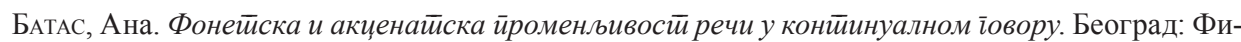
лолошки факултет, 2014. [докторска дисертација].

Ивић, Павле. Расйраве, сӣ⿲guје, чланции. 1. О фонолоїији. Сремски Карловци - Нови Сад: Издавачка књижарница Зорана Стојановића, 1998.

Ивић, Павле, Илсе Лехисте. Прозояија речи и реченице у срйскохрвайском језику. Сремски Карловци - Нови Сад: Издавачка књижарница Зорана Стојановића, 1996.

Ивић, Павле, Илсе ЛЕхисте. О срйскохрвайским акиенииима. Сремски Карловци - Нови Сад: Издавачка књижарница Зорана Стојановића, 2002.

ЈокАновић-МихАллов, Јелица. Природа узлазних акцената у прогресивнијим штокавским говорима. Срйски яијалекииолощки зборник XXIX (1983): 295-338.

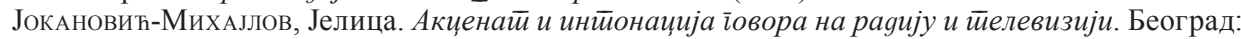
Друштво за српски језик и књижевност Србије, 2007.

ЛАкчевић, Снежана, Љиљана Ђоръввић, Гордана Жикић, Нада Делић, Верица Ристић, Гордана НЕдЕљковић, Драган Вукмировић, Миливоје Грьовић. Сйановнищйво. Школска сйрема,

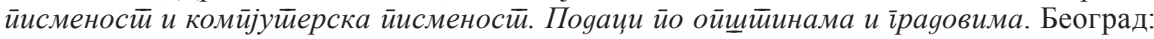
Републички завод за статистику Србије, 2013.

ЛАкчевић, Снежана, Љиљана Ђоръввић, Гордана Жикић, Нада Делић, Верица Ристић, Гордана НЕдељковић, Драган Вукмировић, Миливоје Грьовић. Сйановнищйво. Уйореgни йреїлеg броја стиановника 1948, 1953, 1961, 1971, 1981, 1991, 2002. и 2011. Подации йо насељима. Београд: Републички завод за статистику Србије, 2014.

ЛончАР РАичевић, Александра. Прилог проучавању природе акцената у српском језику. $C p \bar{u}$ ски језик XXI (2016a): 627-639.

ЛончАР РАичЕвић, Александра. Прозоgија речи у їовору ужичкой краја. Бања Лука: Филолошки факултет, 2016б. [докторска дисертација].

ЛончАР РАичввић, Александра, Нина СудимАц. Акустички опис нагласка у говорима призренско-јужноморавског дијалекта. Зборник Матиице срйске за филолоїију и линївисйику LX/2 (2017): 209-225.

Лончар РАичевић, Александра, Нина Судимац. Акустички опис нагласка у говорима тимочко-лужничког дијалекта. Philologia Mediana X/10 (2018): 423-439.

МАрковић, Маја, Исидора БЈелАковић. Квантитет дугих посттоничних вокала у говору Новог Сада. Жарко Бошњаковић (ур.). Говор Новоі Саgа. Св. 1, Фонетиске особине. Нови Сад: Филозофски факултет, Одсек за српски језик и лингвистику, 2009a, 141-147.

МАрковић, Маја, Исидора БЈелАковић. Квантитет наглашених вокала у говору Новог Сада. Жарко Бошњаковић (ур.). Говор Нової Саgа. Св. 1, Фонейске особине. Нови Сад: Филозофски факултет, Одсек за српски језик и лингвистику, 2009б, 148-158.

PMC: Речник срйскохрвайскойа књижевной језика, I-III. Нови Сад - Загреб: Матица српска - Матица хрватска, 1967-1969; IV-VI, Нови Сад: Матица српска, 1967-1976. [коришћено фототипско издање из 1982. године].

СРЕдојевић, Дејан. Експериментално-фонетско испитивање краткоузлазног акцента у новосадском говору - тонска компонента. Жарко Бошњаковић (ур.). Говор Нової Саgа. Св. 1, Фонейске особине. Нови Сад: Филозофски факултет, Одсек за српски језик и лингвистику, 2009а, 159-191.

СРедолевић, Дејан. Акценат именица у језику водитеља-спикера новосадских телевизијских станица. Жарко Бошњаковић (ур.). Говор Ново̄ Сaga. Св. 1, Фонейске особине. Нови Сад: Филозофски факултет, Одсек за српски језик и лингвистику, 2009б, 215-234. 


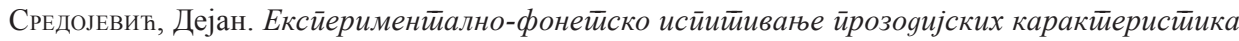
новосаяскої їовора. Нови Сад: Филозофски факултет, 2011. [докторска дисертација].

СРедолевић, Дејан, Наташа СПАсић. Фонетско-фонолошки опис акценатског система стандардног српског као Л2 код говорника којима је мађарски језик матерњи. Зборник Мaйице срйске за филолойју и линівистиику LIX/1 (2016): 57-76.

СРедолевић, Дејан, Љиљана СуБотић. Дугоузлазни акценат у новосадском говору: фонетске карактеристике и фонолошка интерпретација. Зборник Мат̄ище срйске за филолоїију и линївисииику LIV/2 (2011): 108-133.

Дејан Средојевић

Маја Марковић

$$
\begin{gathered}
\text { КВАЛИТЕТСКЕ И КВАНТИТЕТСКЕ ДИСТИНКЦИЈЕ } \\
\text { ИЗМЕЂУ АКЦЕНАТА СТАНДАРДНОГ СРПСКОГ ЈЕЗИКА У ГОВОРУ НОВОГ САДА } \\
\text { (КОРПУС МИНИМАЛНИХ ПАРОВА) }
\end{gathered}
$$

\author{
Рези м е
}

У раду су представљени резултати истраживања квалитетских и квантитетских дистинкција између акцената стандардног српског језика. На основу анализе досад највећег корпуса минималних парова, који се састојао од 832 примера 65 речи, које је реализовало 14 образованих говорника (7 мушког и 7 женског пола), пореклом из Новог Сада, описане су реализације акцената, а да би се утврдило колико се оне међусобно разликују - резултати акустичких мерења (параметара тона, интензитета и трајања) подвргнути су статистичкој анализи. Квалитетске дистинкције најверније одражава распон f0 између краја наглашеног и почетка наредног вокала, који је код силазних акцената силазан, а код узлазних - узлазан. Иако се средње вредности и осталих посматраних параметара тонског и интензитетског односа између наглашеног и наредног вокала статистички значајно разликују између парова речи са силазним, односно, узлазним акцентима, ради се о пратилачким феноменима акценатског квалитета. Наши подаци не подупиру Ивићеву и Лехистину тезу о томе да тонско кретање на наглашеном вокалу може бити дистинктивно у речима с дугим акцентима, ни фонолошко виђење узлазних акцената као двосложних, у значењу које овом термину, следећи Мазингове идеје, дају Ивић и Лехисте. Квантитетске дистинкције између силазних, као и између узлазних акцената, почивају на разликама у трајању наглашених вокала, а делом и на разликама у односу трајања наглашеног и наредног вокала.

Dejan Sredojević

University of Novi Sad

Faculty of Philosophy

Department of Serbian Language and Linguistics

Dr Zorana Đinđića 2, 21000 Novi Sad, Srbija

dsredojevic@ff.uns.ac.rs

Maja Marković

University of Novi Sad

Faculty of Philosophy

Department of English Studies

Dr Zorana Đinđića 2, 21000 Novi Sad, Srbija

majamarkovic@ff.uns.ac.rs
(Примљено: 7. септембра 2020; прихваћено: 28. октобра 2020) 